Ks. Stanisław KOCZWARA

(Zamość, WSD)

\title{
RELIGIJNE MOTYWY W REWOLCIE WITALIANA W 513-515 ROKU
}

Omówiona w niniejszym artykule rewolta Witaliana była krótkim epizodem w historii Bizancjum w pierwszym dwudziestoleciu VI wieku. Choć nie przyniosła ona gwałtownego obalenia władcy w Konstantynopolu ani trwałej zmiany politycznej w Bizancjum, to jednak zakończyła się sukcesem, i to o dziwo, mimo poniesionej klęski militarnej. Wyjaśnienia takiego stanu rzeczy należy szukać w motywach religijnych, jakie odegrały pierwszoplanową rolę w buncie Witaliana. Cel ich był jasny: uznanie katolickich prawd wiary w ujęciu Soboru Chalcedońskiego w całym Kościele Wschodnim i przywrócenie łączności między Bizancjum a Stolicą Apostolską w Rzymie, zerwanej pod koniec V wieku przez schizmę akacjańską. W oczach Witaliana Stolica św. Piotra jawiła się jako obrończyni nieskażonej wiary i gwarant jedności Kościoła. Spektakularny sukces $w$ postaci zakończenia rozłamu, znalazł swoje ukoronowanie w 519 roku, ale poprzedzony został żmudnym wysiłkiem wielu ludzi dobrej woli. Omawiane wystąpienie Witaliana zapisało się w nim na trwałe. Zanim przedstawimy jego przebieg i rezultaty, w wielkim skrócie omówimy wydarzenia poprzedzające, gdyż pozwolą one lepiej zrozumieć sam fakt wybuchu buntu.

\section{I.}

W celu uzyskania religijnego spokoju na Wschodzie, jaki został naruszony w wyniku sporów chrystologicznych, bizantyjski cesarz Zenon (474-491), za namową patriarchy Konstantynopola Akacjusza, wydał religijny edykt pod nazwą Henotikon ${ }^{1}$, który mial pogodzić zwolenników i przeciwników Soboru Chalcedońskiego (451). Zaproponowany kompromis religijny okazał się jed-

${ }^{1}$ Tekst Henotikonu zob. Evagrius Scholasticus, HE III 14, PG 86/2, 2620-2625, thum. S. Kazikowski: Ewagriusz Scholastyk, Historia Kościola, Warszawa 1990, 121-124; zob. także Zacharias Rhetor, HE V 8, ed. E. Brooks, CSCO 87, Syr 41, 157-159. 
nak niemożliwy do zrealizowania, gdyż zbywał on milczeniem uchwały Soboru, a twórcy edyktu pominęli Stolicę Apostolską, której głos w sprawach wiary był zawsze decydujący. Zamiast więc spodziewanej jedności nastąpił dalszy podział; mianowicie obok zwolenników i przeciwników Chalcedonu pojawiła się kolejna siła, to znaczy ci, co przyjęli formułę cesarską ${ }^{2}$.

Wobec takiej postawy ze strony Bizancjum, będącej przejawem cezaropapizmu, papież Feliks III (483- 492) podjąl zdecydowane kroki. Przeciwstawil się cesarskiemu edyktowi i deponowal patriarchę Akacjusza. Ten z kolei nie myślal poddać się papieskiej decyzji, lecz wykreślił imię papieża z kościelnych dyptychów. I tak oto pierwszy otwarty rozłam między Bizancjum a Rzymem stal się faktem trwającym 35 lat $^{3}$. Liczne próby podejmowane w tym okresie z obu stron w celu rozwiązania konfliktu, kończyły się niepowodzeniem ${ }^{4}$. Dopiero wydarzenia z początków panowania następcy Zenona na cesarskim tronie - Anastazego I (491-518) sprawiły, że pojawiła się szansa zakończenia rozłamu. Tuż przed koronacją, której dokonać miał patriarcha Konstantynopola Eufemiusz (489-496), cesarz zobowiązał się na piśmie, że będzie wierny myśli Soboru Chalcedońskiego, zachowując wiarę w całości; to zaś pisemne oświadczenie poparł przysięgą. Cesarz jednak bardzo szybko pozbawił patriarchę złudzeń. Jak tylko poczuł się pewnie na tronie, oskarżył Eufemiusza o spiskowanie z Izauryjczykami i w 496 r. i pozbawil go biskupiej stolicy ${ }^{6}$. Pod wplywem największych przeciwników Chalcedonu, Sewera z Antiochii i Filoksena z Mabbug, którzy w tym czasie przybyli do Konstantynopola, cesarz zacząl się sklaniać wyraźnie ku monofizytyzmowi. Wydał dokument, który przeszedł do historii jako Typos cesarza Anastazego, wrogiego Tomosowi Leona Wielkiego, i posłużył się nim do konsekwentnego usuwania prawowiernych biskupów z ich stolic $^{7}$. W lipcu 511 r. patriarcha Konstantynopola - Macedoniusz został silą

${ }^{2}$ Por. G. Ostrogorski, Dzieje Bizancjum, tłum. zbior., Warszawa 1967, 77; E. Schwartz, Publizistische Sammlungen zum Acacianischen Schisma = Abhandlungen der Bayerischen Akademie der Wissenschaften. Philosophisch-historische Abteilung, Neue Folge, H. 10, München 1934, 171.

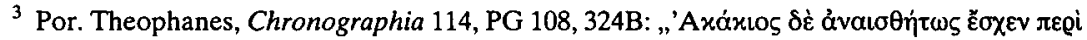

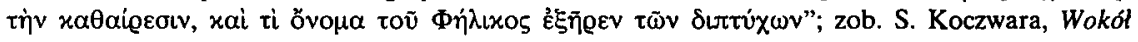
sprawy Akacjusza, Lublin 2000, 59.

${ }^{4}$ Por. Koczwara, Wokót sprawy Akacjusza, s. 64-81 (szczególnie paragraf dotyczący zabiegów papieży Gelazego, Anastazego i Symmacha o przywrócenie jedności).

5 Por. Victor Tonnensis, Chronica, ed. Th. Mommsen, MGHaa XI/2, 192: „Euphemius Constantinopoleos episcopus Anastasii imperatoris calliditate praevisa synodum congregat Calcedonensis synodi decreta confirmat"; zob. Evagrius Scholasticus, HE III 33, Kazikowski s.146.

${ }^{6}$ Por. Theodorus Anagnostes (Lector), HE II 12, PG 86, 190; Marcellinus Komes, Chronicon, MGHaa XI/2, 94; Theopfanes, Chronographia 121, PG 108, 338; R. Janin, Euphemius, DHGE XV $1410-1411$.

${ }^{7}$ Por. Zacharias Rhetor, Vita Severi, ed. M.A. Kugener, PO 2, 108; zob. Ch. Moeller, Un fragment du Type de l'empereur Anastase I, StPatr 3 (1961) 117; C. Capizzi, L'imperatore Anastasio (491-518), Roma 1969, 117. 
zmuszony do zaaprobowania cesarskiego dokumentu. Skarcony przez scytyjskich mnichów, którzy w cesarskiej stolicy byli prawdziwym bastionem katolicyzmu, wycofal się jednak z tego, potwierdzając swoje oddanie Soborowi Chalcedońskiemu. Zdobył się nawet na odmowę wydania imperatorowi dokumentu, w którym Anastazy obiecał swoją lojalność prawowiernej wierze. Dla większego bezpieczeństwa kazał nawet zamurować manuskrypt w ołtarzu kościoła Hagia Sophia. Niestety dokument został wykradziony i dostarczony cesarzowi ${ }^{8}$. Los Macedoniusza został wtedy przesądzony. Dnia 6 sierpnia $511 \mathrm{r}$. zwołany $z$ woli imperatora synod pozbawił go urzędu i patriarcha poszedl na wygnanie do Euchavites śladem swego poprzednika Eufemiusza?.

Podobny los spotkał patriarchów - Flawiana z Antiochii i Eliasza z Jerozolimy. Na synodzie w Sydonie, który został zwołany zimą 511-512 r. w celu potępienia Chalcedonu i usunięcia wyżej wspomnianych patriarchów, ci ostatni zyskali poparcie większości na przekór ich przeciwnikom. Doszło do poważnych zamieszek, w wyniku których, cesarz zdecydował się na usunięcie ze stolicy biskupiej w Antiochii prawowiernego Flawiana, a na jego miejsce powołal monofizytę Sewera ${ }^{10}$. Ten sam los spotkał patriarchę Jerozolimy Eliasza: zniesławiony wobec wiernych, został wygnany mimo podeszłego wieku do Aily (Elath) nad Morzem Czerwonym ${ }^{11}$.

Miara poczynań na rzecz monofizytyzmu się przebrała, gdy Marinus z Apamei zaczął z rozkazu władcy zmuszać duchowieństwo i lud stolicy do śpiewania Trishagionu $\mathrm{z}$ dodatkiem teopasyjnym. Potraktowano to jako prowokację ze strony monofizytów. Wystąpili wówczas zwolennicy usuniętego patriarchy Macedoniusza i doszło w Konstantynopolu do rozruchów. Spalono domy Marinusa, żołnierzy tłum obrzucił kamieniami, po czym zażądał od imperatora zrzeczenia się władzy. Anastazy istotnie wobec zebranego w hipodromie thumu oznajmił gotowość do abdykacji, co uspokoiło zebranych. Gdy tylko ludność rozeszła się do domów, przebiegły władca kazał aresztować przywódców buntu ${ }^{12}$.

${ }^{8}$ Por. Theopfanes, Chronographia 133, PG 108, 366; zob. W.H.C. Frend, The fall of Macedonius in 511 a suggestion, Göttingen 1979, 1-16.

${ }^{9}$ Por. Evagrius Scholasticus, HE III 32, PG 86/2, 2665, Kazikowski s. 146; Marcellinus Komes, Chronicon, MGHaa XI/2, 97; Liberatus, Breviarium causae Nestorianorum et Eutychianorum, w: ACO II vol. 5, s. 133. Liberatus podkreśla, ze stało się to głównie za radą Sewera.

${ }^{10}$ Por. Euthymius, Annales 140, PG 111, 1064; zob. Schwartz, Publizistische Sammlungen, s. 241.

11 Por. R. Janin, Elie, DHGE XIV 189; Capizzi, L'imperatore Anastasio, s. 122.

12 Por. Victor Tonnensis, Chronica, MGHaa XI/2, 196; zob. E. Stein, Histoire du Bas-Empire, II, Paris 1949, 178-179. 
II.

Omówione wydarzenia były jednak tylko przygrywką do o wiele bardziej groźnego wystąpienia, jakim była tytułowa rewolta Witaliana. Charakterystyczne jest to, że rozpoczęła się na terenach europejskich Cesarstwa, zwłaszcza w prowincjach naddunajskich, gdzie obrońcy Chalcedonu byli w znakomitej większości i tworzyli silną opozycję wobec polityki religijnej cesarza ${ }^{13}$. W $513 \mathrm{r}$. syn wybitnego Gota Patriciolusa Witalian, który stał na czele oddziałów sprzymierzonych (foederati), stacjonujących na terenie Tracji, wystąpil przeciw cesarzowi. Powodem były ograniczenia przywilejów (annonae foederaticae), jakie przysługiwały „sprzymierzonym”, przez cesarskiego siostrzeńca Hypacjusza, który pełnił funkcję magister militum per Thraciam. Wykorzystując wzburzenie zołnierzy, kolonów i zwerbowanych Bułgarów, zebrał Witalian 50-tysięczną armię i ruszył na Konstantynopol, rozbijając obóz w Hebdomon ${ }^{14}$. Opierając się na wspomnianej opozycji chalcedońskiej z prowincji naddunajskich, buntownik, który miał ponadto bardzo bliskie więzi $\mathrm{z}$ wypędzonym patriarchą Antiochii Flawianem, ogłosił się obrońcą katolickiej wiary w szacie chalcedońskiej. Cesarz Anastazy widząc realne zagrożenie poczuł się zmuszony do podjęcia rozmów z buntownikami. W tym celu wysłał Patrycjusza - magister militum in praesenti, by prowadził w jego imieniu rozmowy $z$ Witalianem. Obaj byli sobie znani, gdyż podczas wojny perskiej w latach 502-505 Patrycjusz udzielił Witalianowi pomocy. W trakcie rozmów ustalono, że zbuntowane oddziały okażą posłuszeństwo cesarzowi, jeśli naprawione zostaną szkody wyrządzone im przez Hypacjusza. Następny punkt rokowań ujawnia, że ogłoszenie się obrońcą Chalcedonu przez Witaliana nie było czymś pozornym, lecz prawdziwym co do istoty. Zażądał bowiem od cesarza, by przywrócił wiarę katolicką poprzez zwołanie soboru, na którym papież jako przewodniczący obradom mógłby uporządkować sprawy kościelne ${ }^{15}$. Gdy po ośmiu dniach Witalian wycofał się spod Konstantynopola, cesarz jednak nie myślał o dotrzymaniu obietnic, które dał pod wpływem strachu. Odwołał Hypacjusza zastępując go doświadczonym żołnierzem Cyrylem z Ilirii, który prawdopodobnie otrzymał od cesarza polecenie zgładzenia Witaliana. Zbuntowany Got okazał się jednak bardziej sprytny: poinformowany potajemnie uprzedzil Cyryla zaskakując go

${ }^{13}$ Por. A. Fliche - V. Martin, Histoire de l'Église, IV, Paris 1945, 318.

14 Por. Marcellinus Komes, Chronicon, MGHaa XI/2, 98-99; Joannes Malalas, Chronographia XVI, PG 97, 595-596; Evagrius Scholasticus, HE III 43, PG 86/2, 2696, Kazikowski s. 165-166; Capizzi, L'imperatore Anastasio, s. 123 (autor w przypisie128 podaje obfitą literaturę na ten temat).

15 Por. Johannis Antiocheni Fragmenta 1, w: Fragmenta historicorum graecorum (= FHG),

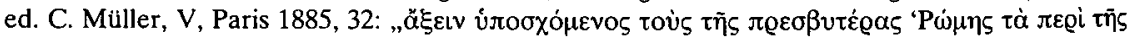

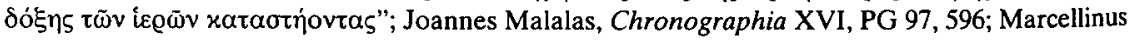
Komes, Chronicon, MGHaa XI/2, 98: ,pro orthodoxorum se fide proque Macedonio urbis episcopo incassum ab Anastasio principe exulato Constantinopolim accessisse asserens". 
nocą. Będący w przymierzu z Witalianem Hun Tarrach zgładził Cyryla w okrutny sposób ${ }^{16}$. Był to wystarczający powód dla cesarza i senatu, aby w Bizancjum ogłosić Witaliana głównym wrogiem państwa. Anastazy zebrał 80-tysięczną armię, powierzył jej dowództwo na nowo Hypacjuszowi, który wyruszył na rebeliantów. Na początku walk buntownicy doznali nieznacznej porażki, lecz wkrótce Witalian doprowadził do wielkiej bitwy w okolicach Odyssus (dzisiejszej Warny), w której rozbił w puch cesarską armię. Hypacjusz dostał się do niewoli, tereny Scytii, Mezji i Tracji znalazły się w rękach rebeliantów, którzy zajęli ponadto ważne miasto Sozopolis. Tam zwycięski Witalian kazał aresztować cesarskich wysłańców wiozących ze sobą okup za Hypacjusza. W marcu 514 roku staną znowu pod murami Konstantynopola ${ }^{17}$. W stolicy sytuacja wyglądała niepokojąco dla cesarza. Wybuchły nowe zamieszki wśród ludności miasta. Zamierzał to wykorzystać Witalian, uderzając na miasto zarówno od strony morza, jak i lądu. Cesarz wiedząc doskonale, że nie jest w stanie odeprzeć ataku, podjął na nowo rokowania: do prowadzenia rozmów wysłał Jana - syna Waleriany, siostry Witaliana. W trakcie rokowań ustalono pokój na następujących warunkach: po pierwsze - sam przywódca rewolty oprócz znacznych ilości złota otrzymał funkcję magister militum per Thraciam, po drugie - Hypacjusz miał odzyskać wolność za wysokim okupem (9000 funtów złota), po trzecie - cesarz zobowiązany został do przywrócenia $\mathrm{z}$ wygnania usuniętych ze swych stolic biskupów Flawiana i Macedoniusza oraz do zwołania soboru w Heraklei w Tracji w celu usunięcia rozłamu w Kościele. Przewodnictwo na soborze miało należeć do Stolicy Apostolskiej, więc imperator musiał nawiązać rozmowy z Rzymem. Także Witalian zastrzegł sobie prawo do wysłania supliki do papieża, by ten dokładnie zbadał sprawę wygnanych biskupów ${ }^{18}$.

Cesarz tym razem dotrzymał słowa. Obawiając się rozszerzenia rewolty Witaliana, który w międzyczasie nawiązał ożywione kontakty z Teodorykiem Wielkim, co groziło możliwością najazdu Ostrogotów na tereny Bizancjum, skierowal do Rzymu dwa listy, w których zaprasza papieża na przewidywany sobór ${ }^{19}$. Papież Hormizdas (514-523) doskonale orientował się, co było główną przyczyną rozpoczęcia rozmów, gdyż spotykał się z wysłannikami Witaliana. Po odbyciu synodu w Rzymie i po spotkaniu z królem Teodorykiem, papież po-

${ }^{16}$ Marcellinus Komes, Chronicon, MGHaa XI/2, 98; Capizzi, L'imperatore Anastasio, s. 124.

17 Zacharias Rhetor, HE VII 7, CSCO 87, Syr 41, 39; P. Peeters, Hypatius et Vitalien, w: Pankarpeia: Mélanges de Henry Grégoire = „L'Annuaire de l'Institut de Philologie et d'Histoire Orientales et Slaves" 2 (1950) 12.

${ }^{18}$ Por. Indiculus Ennodio et Fortunato datus 21-24, w: Epistulae imperatorum, pontificum, aliorum (ann. 367-533) [= Collectio Avellana nr 116], CSEL 35, 518; Schwartz, Publizistische Sammlungen, s. 251.

${ }^{19}$ Por. Epistolae Anastasii ad Hormisdam papam, w: Collectio Avellana, nr 109 i nr 107, CSEL 35, 499-502; Theophanes, Chronographia 138, PG 108, 375. 
stanowił nie odrzucać cesarskiego zaproszenia na sobór $r^{20}$. W tym celu wysłał swoją legację do Konstantynopola. Tworzyli ją Ennodiusz - biskup z Ticinium (Pawii), Fortunat - biskup z Katanii, kapłan Wenancjusz, diakon Witalis i notariusz Hilary. Mieli oni w bezpośrednich rozmowach ustalić wszystko z wyraźnym zastrzeżeniem, że spełnione zostaną wszystkie żądania Stolicy Apostolskiej odnośnie zakończenia rozlamu w Kościele. Były zaś one następujące:

1. Uznanie przez cesarza Soboru Chalcedońskiego poprzez wydanie okólnika (sacra generalia) do wszystkich biskupów Wschodu,

2. Uroczysta aprobata powyższego warunku przez biskupów w obecności wiernych, polączona z potępieniem między innymi Akacjusza,

3. Przekazanie osądowi papieża sprawy wygnanych biskupów,

4. Zastrzeżenie wyroku papieżowi, co do biskupów prześladujących katolików.

Do tego dołączone zostało pismo papieskie (libellus fidei) zawierające w swej treści uznanie Stolicy Apostolskiej za strażniczkę nieskażonej wiary. Należało ją zaakceptować i podpisać, by w ten sposób spełnić warunek niezbędny co do przywrócenia zgody w Kościele ${ }^{21}$.

Lektura tych warunków Stolicy Apostolskiej wyraźnie ukazuje, że żądania wysuwane przez Witaliana, w zasadzie się z nimi pokrywały. $O$ tym, że papież uważał je za bardzo istotne i liczył na poparcie $z$ jego strony, traktując je jako przysłowiowy języczek uwagi w bezpośrednich rokowaniach swoich wysłanników z cesarzem, możemy wywnioskować z lektury instrukcji, jaką mieli ze sobą legaci. Były to najdokładniejsze wskazówki co do ich zachowania w Konstantynopolu ${ }^{22}$. Papież chciał w ten sposób uniknąć przykrych niespodzianek, jakie zdarzyły się w przeszłości legacjom wysyłanym przez jego poprzedników do Konstantynopola ${ }^{23}$. Po przybyciu do Konstantynopola mieli kontaktować się tylko $\mathrm{z}$ tymi, którzy byliby im pomocni w uzyskaniu potrzebnych informacji, co

${ }^{20}$ Por. Liber pontificalis, ed. L. Duchesne, Paris1959, 269; Theophanes, Chronographia, PG 108, 376; Schwartz, Publizistische Sammlungen, s. 251.

21 Warto przytoczyć chociaż niewielki fragment $\mathrm{z}$ tej papieskiej formuły, gdyż wyraźnie wskazuje on na rolę Rzymu w sprawach wiary (Exemplum libelli per Ennodium et Fortunatum 1 i 4): „Pierwszym warunkiem zbawienia jest zachowywanie reguł prawdziwej wiary i niezbaczanie ani na włos od uchwał Ojców. Nie można bowiem nie uwzględniać zdania Jezusa Chrystusa: «Ty jesteś Piotr [Opoka], a na tej opoce zbuduję Kościół mój» (Mt 16, 18). Slowa te potwierdzilo doświadczenie, bo Stolica Apostolska zawsze zachowala religię katolicką bez skazy [...]. Idziemy we wszystkim za Stolicą Apostolską i z uznaniem przyjmujemy jej postanowienia. Dlatego ufam, że stanę się godny pozostać razem z wami w jedności wiary, jaką Stolica Apostolska głosi, w której mieści się cała, prawdziwa i doskonała moc chrześcijańskiej religii" (Collectio Avellana, nr 116b, CSEL 35, 520-521, tłum. A. Bober, Antologia Patrystyczna, Kraków 1966, 307-308).

22 Por. Collectio Avellana, nr 116 (Indiculus Ennodio et Fortunato datus).

${ }^{23}$ Hormizdas miał na myśli legację papieża Feliksa III, wyslaną do Konstantynopola w 483 roku. Wysłannicy papiescy Witalis i Misenus po przejściu typowych dla Bizancjum metodach nacisku, nie wypełnili zadania nałożonego im przez papieża, por. Collectio Avellana, nr 95; Theophanes, Chronographia 114, PG 108, 323; Schwartz, Publizistische Sammlungen, s. 206. 
do sytuacji w stolicy. W czasie audiencji mieli między innymi poinformować cesarza, że mają listy papieża do Witaliana, w których zawarta jest odpowiedź na jego poselstwo skierowane do Rzymu. Mieli też nalegać, by cesarz wręczył go Witalianowi, a gdyby Anastazy zażądał przeczytania listu, legaci mieli odmówić, zasłaniając się brakiem zezwolenia ze strony papieża ${ }^{24}$. Swiadczy to o tym, że zarówno Hormizdas jak i król Teodoryk Wielki, z którym się papież konsultował, nie mieli złudzeń, iż bez nacisku ze strony przywódcy rewolty legacja niewiele wskóra u cesarza. Witalian miał występować w charakterze reprezentanta Stolicy Apostolskiej z zastrzeżeniem, że przyjmie papieską formułę (libellus) i podpisaną wyśle do Rzymu ${ }^{25}$. Istotnie, sukces rewolty Witaliana oznaczał silne poparcie dla obrońców Chalcedonu związanych z Rzymem. Nie tylko biskupi prowincji Dacji, którzy podlegali Konstantynopolowi dołączyli się do żądań wysuwanych przez Rzym i to jeszcze w czasie, gdy na Stolicy św. Piotra zasiadał poprzednik Hormizdasa papież Symmach ${ }^{26}$, ale i inni jak to zobaczymy niebawem. Tymczasem sytuacja wyglądała następująco: Witalian uznał, że należy podjąć działania, które miały być formą nacisku na cesarza przy trwających rozmowach. Jesienią $515 \mathrm{r}$. wpłynął ze swoją flotą do Bosforu. Tym razem jednak cesarz przewidział atak. Izauryjski garnizon w Sykai (Galata) odparł uderzenie rebeliantów, a wypływająca ze Złotego Rogu flotyllę zniszczono $^{27}$, maszerujące zaś na Anaplus oddziały cesarskie miały Witalianowi przeciąć drogę odwrotu. Wódz rebelii ratować się musiał szybką ucieczką do Anchialos, gdzie przebywał bezpieczny wprawdzie o swoje życie, ale pozbawiony przywództwa nad Tracją. O narzuceniu swojej woli cesarzowi nie było już mowy. Mógł on bez większego ryzyka wycofać się z polityki dotrzymania warunków pojednania z Rzymem, tym bardziej, że Teodoryk Wielki bez wsparcia ze strony Witaliana nie mógł myśleć o jakiejkolwiek interwencji ${ }^{28}$. Także dla zwołanego początkowo do Heraklei synodu, na który przybyć miało 200 biskupów, taka sytuacja oznaczała przeniesienie się do Konstantynopola, gdzie należało być posłusznym woli cesarza. Ten zaś zadbał o to, by pod koniec 515 r. rozwiązać synod i legatów papieskich odprawić do Rzymu ${ }^{29}$.

${ }^{24}$ Por. Indiculus Ennodio et Fortunato datus 8, w: Collectio Avellana, nr 116, CSEL 35, 514515: „Si imperator petierit epistolas a vobis ad Vitalianum directas, sic respondendum est «non hoc nobis pater vester sanctus papa praecepit nec sine iussione ipsius aliquid possumus facere»".

${ }^{25}$ Por. Schwartz, Publizistische Sammlungen, s. 251.

26 Por. Epistola Orientalium episcoporum ad Symmachum, ed. A. Thiel: Epistolae Romanorum Pontificum genuinae, Braunsbergae 1868 (dalej Thiel), 709-717.

${ }^{27}$ Zwycięskiej cesarskiej flocie przewodzil Marinus, który odniósł zwycięstwo dzięki zastosowaniu greckiego ognia, por. Joannes Malalas, Chronographia XVI, PG 97, 597-599; por. Joannis Antiocheni fragmenta, FHG V 34, gdzie całą właściwie zasługe zwycięstwa autor przypisuje Justynowi, późniejszemu cesarzowi.

28 Por. Schwartz, Publizistische Sammlungen, s. 252.

29 Liber pontificalis, s. 269; Collectio Avellana, nr 125, CSEL 35, 537-540; Thiel, nr 10 (Epistola Anastasii imperatoris ad Hormisdam papam), s. 761-764. 
A jednak pomimo klęski militarnej rebelia Witaliana przyniosła trwały owoc na polu religijnym. Podniesieni na duchu jego wystąpieniem w obronie Chalcedonu i wygnanych pasterzy, prawowierni biskupi z Ilirii i Dardanii oraz sąsiednich prowincji przystąpili do wspólnoty ze Stolicą Apostolską. Wśród nich prym wiedli Alkison - biskup Nikopolis w Starym Epirze i Wawrzyniec - biskup z Lychnidos (Ochryda) w Nowym Epirze. Kronikarz Teofanes zanotował, że w 515 r. zebrało się 40 biskupów z Ilirii i Grecji, aby wystapić przeciw biskupowi Salonik Doroteuszowi, który nawiązał ożywione kontakty z Tymoteuszem, patriarchą Konstantynopola ${ }^{30}$. Ten ostatni bowiem zdecydowanie stał po stronie cesarza Anastazego. Zebrani biskupi wysłali pismo do papieża z prośbą o przyjęcie ich do jedności, gdyż chcą się poddać zasadom Stolicy Apostolskiej ${ }^{31}$. Nawiązaniu takich bliskich więzi i porozumieniu dopomogło bez wątpienia przebywanie papieskich legatów w Konstantynopolu ${ }^{32}$. Gdy jednak Witalian, który sprawował dyskretną opiekę nad rzymską legacją, został pokonany, cesarz kazał przybyć do Konstantynopola pięciu biskupom z metropolitą Alkisonem na czele ${ }^{33}$; zatrzymano ich w stolicy jako więźniów. Dwaj z nich: Alkison i Gajanus zmarli w Konstantynopolu, zaś Wawrzyńca długo trzymano w więzieniu, nim powrócił do swojej stolicy biskupiej. Dwaj pozostali mieli więcej szczęścia: upomniała się o nich bowiem armia z Ilirii, a z nią kolejnego konfliktu nie życzył sobie cesarz, więc mogli wrócić do swoich siedzib. Metropolita Alkison, korzystając z obecności rzymskich legatów w stolicy, zdążył jeszcze przed śmiercią przekazać im swoją aprobatę postanowień Stolicy Apostolskiej ${ }^{34}$. Po jego śmierci w 516 r. biskupi Starego Epiru

${ }^{30}$ Por. Theophanes, Chronographia 139, PG 108, 378: „Episcopo vero Thessalonicensi ob Imperatoris metum cum Timoteo Cpoleos episcopo communionem tenente, quadraginta Illyrici Graeciaeque episcopi una convenientes, tabulis etiam testibus professi sunt, ab eo, velut a proprio metropolita, se discedere, missique Romam tabulis Romani pontificis communionem observare polliciti sunt".

31 Por. Epistola ad Caesarium Arelatensem, PL 63, 432A: „Ergo episcopi tam Dardani, quam Illyrici pene omnes, $[. .$.$] beati Petri apostolorum principis communionem et scriptis et legationibus$ destinatis se apostolicae sedis regulis obedire confirmant".

${ }^{32}$ Dnia 15 lutego $517 \mathrm{r}$. tak pisal o tym papież do Awita z Vienny (Epistola Hormisdae ad Avitum Vienensem 10): „Epiri metropolitanus, hoc est Nicopolitanus episcopus, cum synodo sua nuper segregatus ab impiis ad apostolicam communionem deprompta, quae id efficeret, professione se contulit" (Collectio Avellana, nr 137, CSEL 35, 563).

33 Por. Marcellinus Komes, Chronicon, MGHaa XI/2, 99: „Laurentium praeterea Lychnidensem, Domnionem Serdicensem, Alcissum Nicopolitanum, Gaianum Naisitanum et Evangelum Pautaliensem, catholicos Illyrici sacerdotes, suis Anastasius praesentari iussit obtutibus".

${ }^{34}$ Fakt przyjęcia Alkisona do wspólnoty z Rzymem poświadczają biskupi Starego Epiru w swoich posłaniach do papieża Hormizdasa (Relatio synodi Epiri Veteris ad Hormisdam papam 2): „plurimi namque ex nobis in regnante fuere Cpoli, cum vestri ss. Vicarii Ennodius etc. degerent [...]; nobiscum fuit et inter sanctos factus pater atque archiepiscopus noster Alcison, qui cum omni praesumptione supplicibus utens libellis apud vestram beatitudinem dignus effectus est apostolicae sedi vestrae communicare nobiscum" (Collectio Avellana, nr 119, CSEL 35, 527. Także sam papież 
wybrali nowego metropolitę Jana, który przez diakona Rufina przesłał do Rzymu prośbę swoją i synodu o przyjęcie do jedności ze Stolicą Apostolską $^{35}$. Na taką suplikę papież Hormizdas odpowiedział wysłaniem subdiakona Puliona, który miał zebrać podpisy pod papieskim orędziem wiary (libellus). Misja ta zakończyła się pełnym sukcesem. Biskupi tych prowincji, do których przybył papieski wysłannik, zaakceptowali formułę Hormizdasa ${ }^{36}$.

Zdecydowana postawa w obronie Chalcedonu wyżej wspomnianych biskupów, wywołana wystąpieniem Witaliana, znalazła żywy oddźwięk aż w Palestynie, gdzie mnisi wrogo nastawieni do monofizytyzmu napisali do Alkisona i jego współbraci długi list, w którym opowiedzieli wszystko, co wycierpieli stojąc wiernie przy Chalcedonie. List zawierał też pragnienie żywej łączności z tymi, do których był skierowany ${ }^{37}$. Także z Syrii przyszła wiadomość, że wielu biskupów i mnichów przyjęło papieską formułę wiary. Wystosowali oni do papieża list, w którym w pięknych słowach proszą, by Hormizdas pamiętał o nich zwłaszcza $w$ tedy, gdy doznają wiele cierpień z powodu wiernego trwania przy prawowiernej wierze ${ }^{38}$. Hasła religijne, tak zdecydowanie podniesione przez Witaliana, znalazły na Wschodzie żywy oddźwięk. Coraz bardziej zaczęto tutaj zdawać sobie sprawę, że trwający rozłam między papieskim Rzymem a Konstantynopolem do niczego dobrego nie doprowadzi, a zatem należy go przezwyciężyć $w$ oparciu o niezmienność wiary katolickiej, a tej strażniczką była Stolica Apostolska. Wprawdzie nie nastąpiło to za rządów Anastazego I, gdyż ten wyraźnie skłaniał się ku monofizytyzmowi, i tak już pozostało aż do jego śmierci w 518 r., ale już jego następca, cesarz Justyn, podjął zdecydowane kroki mające przywrócić upragnioną jedność w Kościele. Wspierał go w tym wszystkim jego siostrzeniec Justynian, późniejszy cesarz, który faktycznie był „spiritus movens” całej polityki religijnej wuja. Jego pragnieniem było odzyskanie zachodniej części cesarstwa, a do tego celu wiodło przywrócenie pełnej jedności ze Stolicą Apostolską w Rzymie. Zarówno Justyn, jak i Justynian nie mogli pominąć w tym dziele osoby Witaliana, tym bardziej, że ów wciąż miał pod sobą własną, oddaną mu armię i był

w liście do swoich legatów pisal: „Alcison episcopus Constantinopoli satisfecit Ecclesiae catholicae, susceptus est et ad communionem reductus" (Collectio Avellana, nr 135, CSEL 35, 557).

${ }^{35}$ Por. Epistola Symmachi ad Caesarianum Arelatensem. Collectio Avellana, nr 117; Thiel, nr 15, s. 723-728.

${ }^{36}$ Por. Epistola Ennodii ad Symmachum papam. Collectio Avellana, nr 124; Thiel, nr 23, s. 733-734.

${ }^{37}$ Por. Evagrius Scholasticus, HE III 31, PG 86/2, 2660-2664, Kazikowski s. 142-145 (List mnichów palestyńskich do Alkisona); L. Duchesne, L'Église au VI' siècle, Paris 1925, 30-31.

38 Por. Exemplum relationis minimorum archimandritarum 5. Collectio Avellana, nr 139 , CSEL 35, 566-567: „Euntibus namque nobis ad mandram domni Simeonis pro causa ecclesiae insidiati sunt nobis in itinere praedictis coinquinati et supervenientes occiderunt ex nobis trecentos quinquaginta viros, quosdam autem vulneraverunt: alios vero, qui potuerunt ad colenda altaria refugere, ibidem peremerunt et monasteria incenderunt". 
w stolicy, zwłaszcza w środowisku mnichów scytyjskich postacią niezwykle popularną. Nawiązali więc z nim łączność. W kościele św. Eufemii w Chalcedonie, gdzie obradował sławny sobór, złożyli przysięgę i wszyscy trzej przybyli do Konstantynopola. Po kilku dniach Witalian otrzymał stanowisko dowódcy gwardii pałacowej z tytułem patrycjusza, a następnie konsulat na $520 \mathrm{rok}^{39}$. Cesarz podjął program Witaliana w całości, a gdy ten oburzony na wybryki Sewera z Antiochii zażądał ni mniej ni więcej tylko obcięcia mu języka, to natychmiast Ireneusz, prefekt pretorium Wschodu, otrzymał od cesarza rozkaz ujęcia Sewera, który jednak zdołał umknąć do Egiptu ${ }^{40}$. Witalian wespół z Justynianem podjęli ożywioną działalność, mającą na celu przywrócenie w całym Cesarstwie zasad Chalcedonu i pojednania z Rzymem św. Piotra ${ }^{41}$. Do nich dołączy patriarcha Konstantynopola Jan II, a szczerość ich długich wysiłków przyniesie wreszcie upragnioną jedność. Dnia 25 marca 519 r. dotarła do Konstantynopola legacja papieska. Stolica powitała ją z niezwykłym entuzjazmem: naprzeciw papieskim wysłańcom wyszły na 10 mil przed miasto najwybitniejsze osobistości w Cesarstwie. Wśród nich był Witalian. Parę dni później, 28 marca, po przyjęciu papieskiej formuły zjednoczeniowej przez patriarchę Konstantynopola Jana i pozostałych, obecnych w tym dniu biskupów wschodnich, mógł cieszyć się wraz z całym senatem, duchowieństwem i ludnością Konstantynopola z przywróconej jedności kościelnej. Jego inspirowane wiarą postulaty, $z$ jakimi wystąpił wzniecając rewoltę w 512 r. teraz wprzęgnięte w oficjalną politykę cesarza, zostały spełnione.

Motywy religijne, jakimi się kierował, nawet jeśli kryły się za nimi jeszcze inne względy, także polityczne, były podjęte szczerze. Konsekwencja w ich stawianiu jako warunków do wypełnienia w negocjacjach z cesarzem, poinformowanie o nich króla Ostrogotów Teodoryka Wielkiego, ktờry był arianinem, wreszcie przedstawienie ich do akceptacji przez Stolicę Apostolską, świadczą o żywym przywiązaniu do katolicyzmu w wydaniu chalcedońskim. Rozumiał też Witalian lepiej niż kto inny w tym czasie, że zapewnienie jej należytego miejsca w Bizancjum nie jest możliwe bez pełnej jedności ze stolicą św. Piotra w Rzymie.

Oceniając jego wystąpienie, możemy bez cienia wątpliwości powiedzieć, że był człowiekiem swojego czasu, tzn. uwzględniał wszystkie aspekty życia publicznego, w którym wiara odgrywała rolę najistotniejszą. Chrześcijaństwo było stymulatorem tego życia pojętego - w świetle ewangelicznym - jako dobro powszechne.

${ }^{39}$ Por. Marcellinus Komes, Chronicon, MGHaa XI/2, 101; Schwartz, Publizistische Sammlungen, s. 259.

40 Por. Zacharias Rhetor, HE VII, CSCO 87, Syr 41, 39; Theophanes, Chronographia 142, PG 108, 383-384.

${ }^{41}$ Por. A.A. Vasiliev, Justin the First. An Introduction to the Epoch of Justinian the Great, Cambridge Mass. 1950, 135. 
Poruszając się w konwencji traktowania historii jako nauczycielki życia, mamy prawo skonstatować, że proces wyeliminowania religii z życia publicznego, tak charakterystyczny dla naszego czasu, prowadzi do nikąd. O ile mniej jej w tym życiu, o tyle uboższy staje się sam człowiek. W podjętych przez obie strony (Witaliana i cesarza) rokowaniach, dostrzega się pełne ujęcie bytowania życia ludzkiego w każdym czasie, a więc jego wymiar materialny, co przejawiło się $w$ trosce o należyte wynagrodzenie żolnierzy; wymiar moralny, widoczny w upomnieniu się o pokrzywdzonych pasterzy i wreszcie wymiar religijny znaczący się troską o należne miejsce w państwie dla katolickiej wiary. Ta ostatnia pojmowana była jako najsilniejsza kuźnia tego wszystkiego, co twórcze i odpowiedzialne. Warto o tym pamiętać. Dla tych więc, co prowadzą dziśs rozmaite negocjacje dotyczące urządzenia życia całych społeczeństw, a czynią to bez uwzględnienia zasad wiary chrześcijańskiej, motywy religijne wystąpienia Witaliana warte są przypomnienia.

\section{THE RELIGIOUS MOTIVES IN VITALIAN'S REVOLT IN 513-514}

(Summary)

The short of the first twenty years of VI century of Byzantium's history when political changes in Constantinopole took place was described in the article The religious motives in Vitalian's revolt in 513-514. The leader of the rebellion indicated two aspects oh his pronouncement as the most important ones. They were restoration of the religious union on the East based on resolutions of The Chalcedonian Council and recognition of the leading role of The Apostolic See in the filed of guarding religious authenticity. Despite the military defeat Vitalian's revolt ended with success on the religious field. 